\title{
The Root Of Islamic Fundamentalism in The Political Thoughts Of Al-Maududi and Sayyid Qutb: A Historical Study
}

\author{
Ilman Nafi'a \\ Septi Gumiandari \\ Tarbiyah and Teacher Training Faculty, IAIN Syekh Nurjati Cirebon \\ ilmannafiāsyekhnurjati.ac.id \\ septigumiandarisyekhnurjati.ac.id
}

\begin{abstract}
Al-Maududi and Qutb are two Islamic thinkers who are often claimed to be figures of Islamic fundamentalism. The thoughts of these two figures are strongly suspected have an influence on the emergence of the spirit of fundamentalists in various parts of the Islamic world to establish an Islamic state. It is here that the significance of the historical study of Islamic political thought of the two figures is important to reveal. Through a literature review, this paper aims to find out the differences and similarities in the political vision between al-Maududi and Sayyid Quthb regarding the form of the State. The results of the text review of the thoughts of the two figures show that both ideas characterized more constructive suggestions for the administration of an Islamic state, rather than offering a concrete form of government. Although both have a similar obsession about the Islamic state, the strategies adopted by both of them in reaching their obsession have differences. Maududi was more inclined to the form of cultural movements, while Qutb was more likely to choose revolutionary movement.
\end{abstract}

Key Words: Islamic Fundamentalism, Political Thought, History

\section{INTRODUCTION}

Islamic fundamentalism has become one of the most popular discourses in this modern era. As a movement, Islamic fundamentalism has become a very frightening movement for the world community in this century. The label "Islamic fundamentalism" or "Muslim fundamentalist" is widely raised by the mass media against contemporary Islamic revival movements such as Hamas, Hezbollah, Muslim Brotherhood, Islamic Jama'at, and Hizb utTahrir Al-Islamy. The use of the term fundamentalism alleged by the mass media of these movements of contemporary Islamic revival, Besides aiming to give a minor picture of their various activities, they also want to drop their "credibility" in the eyes of the world.

In the beginning, Islamic fundamentalism was often used as a religious movement in responding to the development of global life, but later it was used in political movements by fighting for the Islamic State and its symbols. An ideology that often has the function of 
arousing militancy and radicalism of the people. ${ }^{1}$ Furthermore, this fundamentalism is realized in the context of the implementation of Islamic law which is considered as an alternative solution to the nation's crisis. They want to implement Islamic law holistically (kaffah) with a literal or textual interpretation approach to the messages of the Koran.

In the study of Islamic politics today, there are at least two major views related to the concept of the state. First, the view of the country without borders or khilafat. This view is inspired by the view of Islamic universality which is not limited by the state and nation (supranational). For this reason, this view does not agree with the existence of a national and state ideology formed on the basis of territory, nation or other identities. ${ }^{2}$ Second, the idea of a form of state that is based on the ideology of nationalism or nationalism which is often referred to as nation-state. This view departs from the reality that the world community is mapped with one another, not only because of geographical differences, but also has socio-cultural and other differences that ultimately shape countries based on their respective identities. ${ }^{3}$ Although there is a very clear contradiction between the view of khilafat and the nation-state, but the fact that the form of the nation-state has inspired the majority of the countries inhabited by the majority of Muslims. ${ }^{4}$

As far as practical political movements are concerned, al-Maududi and Qutb are two of the Islamic thinkers who are interested and involved in debating the issue above. ${ }^{5}$ Both of them are often claimed as figures of Islamic fundamentalism. This is because both of them are included in the list of figures who made the benchmarks of Islamic doctrine in the early days of

${ }^{1}$ John L. Esposito, Dinamika Kebangkitan Islam; Watak, Proses dan Tantangan, (Jakarta: Rajawali Press, 1987), p. 154-155. Look at too Ali Rahmena, Para Perintis Zaman Baru Islam, (Bandung: Mizan, 1996), p. 111-112.

${ }^{2}$ P.J. Vatikiotis, Islam And The State, (London And New York: Routledge, 1987), p. 36.

${ }^{3}$ According to Abdurrahman Wahid, the biggest difficulty in looking for the relationship between Islam and the concept of nationalism lies in the seemingly supranational nature of Islam. Like all religions, Islam extends to humanity as a whole, regardless of its ethnic origin. Of course it is very difficult to incorporate Islamic values into the ideological construct of a national nature. If forced too, it means that the life insight brought by Islam must be subjected to the national insight of an ideology. And this also triggers the idea of an Islamic state (Abdurrahwan Wahid, Mencari Format Hubungan Agama Dengan Negara, dalam Kacung Marijan (Ed), Mengurai Hubungan Agama dan Negara, (Jakarta: Grasindo, 1999), p. 72-73)

${ }^{4}$ A. Syafii Ma'arif explained that the idea of a nation state in the Islamic world had encouraged Muslims to affirm their identity in the nation-state system. This system often destroys the vision of Islamic universalism. But he also said that his existence was a reality that must be passed. And he believes that his existence in the Islamic world will not last long, because for Islam, fellow Muslims are brothers and sisters inseparable from ethnic identity. Nationalism for him is a pseudo religion (A Syafii Ma'arif, Peta Bumi Intelektualisme Islam di Indonesia, (Bandung: Mizan, 1993), p. 207). A similar opinion was conveyed by Rashid Ridho, quoted by John L. Elposito, seeing the concept of nationality as a reality. John L Elposito, Islam and politics, (New York: Syracuse University Press, 1987), p. 63

${ }^{5}$ Munawwir Sadjali, Islanm dan Tatanegara; Ajaran, Sejarah dan Pemikiran, (Jakarta : UI Press, 1990), p. 159 
Islam as a precedent that ties the pattern for the steps of the rise of modern Islam. ${ }^{6}$ Thought of these two figures are strongly suspected of having an influence on the emergence of ideas of fundamentalism and the obsession with the founding of an Islamic state which is now becoming popular echoed to be realized by Muslims in various parts of the Islamic world. ${ }^{7}$

Looking at the variations of the tendency of political thought discourse above, the study of al-Maududi and Sayyid Quthb's figures has a significant proportion to be revealed as influential figures in coloring the political discourse of Muslims today, particularly regarding the form of the State. Although both of them are known as anti-Western figures, in terms of the concept and form of the State, both have quite clear differences, including in various aspects of the political field. ${ }^{8}$

This study aims to determine the differences and similarities in political vision between al-Maududi and Sayyid Quthb, especially regarding the form of the State. Academically, this study of political thought between al-Maududi and Sayyid Quthb is a very significant effort in terms of completing scientific treasury in political science and Islam, where this study is expected to provide a distinctive color to the dynamics of the political development of Muslims in anticipating political parties next year. In addition, praxis, the results of this study are expected to be able to raise awareness among Muslim politicians in particular, to continue their ideas in developing research that supports concepts around the Islamic Political System.

\section{METHOD OF RESEARCH}

This research uses Library Research, where all data comes from written materials related to the characters and topics being discussed. Because this study discusses political thought between al-Maududi and Sayyid Quthb, the first and foremost source is the work of the two figures. Al-Maududi's monumental works are used as sources for al-Khilafah wa al-Mulk and The Islamic Law and Constitution, While the works of Sayyid Qutb are Ma'alim fi al-Tharieq, Fi Dilal al-Qur'an, and al-'Adalah al-Ijtima'iyyah fi al-Islam. Because the material object of this research is the thinking of two Islamic political figures (al-Maududi and Sayyid Quthb) for a certain period of time in the past, methodologically this study uses a political History approach. ${ }^{9}$ To obtain an accurate interpretation of the contents and contents of the thoughts of the two figures, the author uses the Gadamer-style hermeunetic approach. This approach is needed, because the object of study that is not possible to interpret without going through the method of interpretation. In other words, this approach is important as a basis for the writer to

${ }^{6}$ Azyumardi Azra, "Fenomena Fundamentalisme dalam Islam; Survei Historis dan Doktrinal" in Ulum al-Qur'an, nomor 3, Vol IV, 1993, p.. 18-24

${ }^{7}$ Mukti Ali, Alam pikiran Islam Modern di India, (Bandung: Mizan, 1993), Cet. I, p. 262263

${ }^{8}$ Al-Maududi, The Islamic Law and Constitution, (Labore: Islamic Publication, 1975), Edition 5, p. 165. Do compare with Sayyid Quthb, al-'Adalah al-Ijtima'iyyah fi al-Islam, Kairo: Dar al-Shuruq, 1979, p. 93.

${ }^{9}$ Anton Bakker dan Achmad Charris Zubair, Metodologi Penelitian Filsafat, (Yogyakarta: kanisius, 1990), p. 61. 
analyze the language used by the two figures. Whereas in analyzing data, content analysis is used. $^{10}$

\section{DISCUSSION AND RESULT FINDINGS}

\section{1) Brief Biograpy of al-Maududi and His Thought}

His full name is Sayyid Abul A'la al-Maududi. He is one of the important figures in the process of revival of contemporary Islam. He was born on September 25, 1903, to coincide with 3 Rajab 1321 in Awrangabad, southern India. ${ }^{11}$ His father's name was Sayyid Ahmad Hasan. He is the youngest of five siblings. His lineage continued directly with Khwaja Qutbu'ddin Maududi Chisti, from where the name Maududi was taken, which was awarded the title of shaykhul syuyukh (professor) in India. ${ }^{12}$ From his mother, Ruqaiyah Begum, his family came from a main family from Turkey who immigrated to India when Aurangzeb was in power and had held an important post in the Mughal government. In his childhood, Maududi was very loved by his father. The great attention of his father who adheres to Sufism, according to Maududi in his autobiography, has influenced his attitude. Especially in idealism, wisdom and humility. his father, Ahmad Hasan, was very concerned about the education of his children. Therefore, he sees the need to teach his children himself. His father wanted Maududi to become a maulawi (cleric), a naturalist and at the same time as an Islamic thinker. Before his children go to sleep, he always tells about big people in Islam and the greatness of Islamic history. Maududi began his education by learning Persian, Urdu and then Arabic. In addition, he also learned mantiq [logic] of fiqh and hadith. At a very young age, Maududi had an intense desire to write. But the father did not allow it. Instead, he advised his son to read a lot in advance to have a solid foundation and maturity in various sciences.

There are two important events that prompted Maududi to take the role of leader, Islamic thinker and as a spokesperson to spread Islamic ideas as an alternative conception in community and state life. ${ }^{13}$ First, regarding the killing of a Hindu revivalist figure, Swami Shradhanand, by an extremist Muslim who believes that one of the duties of religion for every Muslim is to kill infidels. This event sparked open debate. In the debate, allegations emerged that Islam was broadcast with the sword (violence). It was this polemic which then knocked on al-Maududi's heart to write a book called al-Jihad fii al-Islami. This book not

\footnotetext{
${ }^{10}$ Klaus Krippendorff, Content Analysis; Introduction to Its Theory and Methodology. Translated by Farid Wajidi, (Jakarta: Rajawali Press, 1981), p. 15.

${ }^{11}$ Sayyid Vali Reza Nasr in Ali Rahnema, Para Perintis Zaman Baru Islam, (Bandung, Mizan: 1996), p. 102

${ }^{12}$ Ali Rahnema, Zaman Baru Islam, p. 102

${ }^{13}$ Munawir Sadjali, Islam dan Tatanegara; Ajaran, Sejarah dan pemikiran, (Jakarta: UI Press, 1990), p. 159.
} 
only explains the Islamic attitude about war (violence), but also introduces the points of thought which later develop into an Islamic concept of social life and statehood.

The second event was the independence movement in India, especially regarding the future of the lives of Muslims and Hindus when it was freed from the shackles of British colonialism in 1930. When Indians consisting of Hindus and Muslims urged independence from Britain, Maududi strongly opposed the opinion of Mahatma Ghandi was inclined to the Hindus and he also opposed the opinion of Ali Jinnah who offered the theory of the Two Nations. Maududi continued to state that the order of life of Muslims was different from Hinduism. Islam has special moral values, therefore it is very impossible to unite them in one country.

Departing from these two events, several formulations of political thought were born, which he outlined in many of his political works. Of the many books he wrote, his political thought can be traced, especially in the book of al-Khilafah wa al-Mulk, al-Daulah alIslamiyyah, al-Jihaad Fil Islam, al-Hukumah al-Islamiyah wa maa Yataallaku biha, dan al'Aqaaid wal-Ilahiyyat wa Mabaadi al-Islam al-Asasiyyah. His political vision is basically seen clearly through three basic principles underlying Maududi's thoughts about Islamic statehood (a) Islam is a complete religion, complete with instructions to regulate all aspects of human life, including political life (in Islam there is a political system) by imitating political patterns during the time of Khulafa al-Rashidin; (b) The highest power, which in political terms is called sovereignty is in the hands of God, while humanity is merely executing His sovereignty as the caliph of Allah; and (c) The Islamic political system is a universal system and it does not see geographical, linguistic and national boundaries.

Based on the three basic beliefs or assumptions, the conception of Islamic state was born, the main points are as follows: ${ }^{14}$

\section{a) The Birth of a Country}

According to al-Maududi, the obligation of a state is based on rational considerations. The reason for the birth of the state is departing from the need for the universal order above. According to him, the Islamic state is part of a broadly integrated theology, whose main principle is the sovereignty of God the owner of nature. Islamic shari'a does not recognize the separation between religious practices and aspects of life. The most special is between the state and religion.

He argued that the Qur'an not only lays down the principles of morality and ethics, but also provides guidance in the political, social and economic fields. Penalties are also specified for certain crimes and so are the principles of fiscal and monetary policy. This all cannot be practiced unless an Islamic state will uphold it. And herein lies the need for an Islamic state. This concept is explained by the Qur'an in the verse QS. 24: 2. ${ }^{15}$

\section{b) Mechanism for Election of Government Officials.}

${ }^{14}$ Al-Maududi, The Islamic Law and Constitution, p. 165

${ }^{15}$ Al-Maududi, The Islamic Law and Constitution, p. 171. 
The existence of a country cannot be separated from the existence of a head of state. So in this case the two parties are responsible, namely Ahl al-Ikhtiyar and Ahl al-Imamah. The first is an institution that represents the people and is obliged to elect and appoint the head of state and the second is the one who has the competency to occupy the position concerned.

Ahl al-Ikhtiyar is required to equip himself with several conditions. Likewise with $A h l$ al-Imamah, his competence is also determined by his fulfillment of certain requirements. $A h l$ al-ikhtiyar is required to consist of citizens who are Muslim, adult and male, who are counted as pious and trained enough to interpret and establish sharia and formulate laws that do not conflict with the Qur'an and the Sunnah of the prophet. Whereas ahl al-Imamah is required to consist of a Muslim, male, adult, physically and mentally healthy, the best citizen, pious and strong commitment to Islam. ${ }^{16}$

Regarding the selection of ahl al-Imamah (head of state), Maududi did not limit the scope of possibilities by specifying details about how the election of the leader would be carried out. According to him, various ways might be suitable for various times and circumstances, as evidenced by the lack of uniformity in the ways of determining the replacement of the first four khilafat after the Prophet died. The most important thing according to him is that the elected leader must obtain full trust from the nation, and occurs as long as three principles are fulfilled: (a) in a country, the election of the head of state depends entirely on the general public, and no one has the right to appoint themselves by force or violence, (b) No clan or group has a monopoly on this position, and (c) elections must be held with the principle of free will of Muslims and without coercion or threats.

Some considerations applied to the determination of ahl al-Imamah, also apply in the formation of a legislative body (ahl al-Ikhtiyar), which exists among the main institutions of the Islamic state. In the fourth period of khulafa al-Rashidin, this body was not elected, and according to Maududi this was due to the situation at that time. The important thing about the selection process is that it must produce the best choices or people, and in any way the results will be achieved. Ability that must be possessed by a legislative body is a person who is able to: (a) formulate in legislation, instructions clearly contained in the Qur'an and hadith and its implementing regulations, (b) if there are differences in interpretation of al-Qur'an and hadith, then decide which interpretation is set, (c) if there are no clear instructions, determine the law with due regard to the spirit or general instructions of the two books, and (d) in the event that there are no instructions at all basic instructions, can only compile and ratify the law, as long as it does not conflict with the letter and the Shari'a soul.

Besides the two government institutions above, Maududi occasionally mentions the judiciary as a fundamental institution, but the attention he gives to this institution is very little, even the available material is insufficient to cover his thoughts in full. Neither do certain other institutions, such as the Bait al-Mal (state treasury), which are also discussed briefly. There is no clear picture of the nature, power and function. ${ }^{17}$

\footnotetext{
${ }^{16}$ Al-Maududi, Al-Khilafah wa al-Mulk, (Bandung: Mizan, 1996), p. 37.

${ }^{17}$ Al-Maududi, The Islamic Law and Constitution, p. 175.
} 


\section{c) Dismissal of the Head of State from his Office.}

What is also interesting from al-Maududi's political thinking is his formulation of the dismissal of the head of state from his position. According to him, the head of state can be dismissed from his position if it turns out to have deviated from justice, or distorted and failed in carrying out the mandate of the people. But like Mawardi, he did not provide further explanation on how the mechanism of dismissing the head of state from his position. Whether through the ahl al-khtiyar trial, referendum, or the cause of the coup.

Neither does the term of office of the head of state. Maududipun did not explain when the head of state resigned from his term of office. Even though limiting the term of office for the head of state is an effective way to stop the abuse of a ruler so as not to be prolonged. He only revealed that the head of state after his term of office could be re-elected, but if it turns out that his leadership during his tenure did not benefit the people, then after the end of his term of office, the people could elect another leader. ${ }^{18}$

\section{d) Nationality.}

In an Islamic state there are two types of citizenship: one type for Muslims who live in the territory of the country, and another type for those who are not Muslims, who agree to be loyal and obedient to the Islamic country where they live.

Muslims have full responsibility for the running of the government. They must accept the obligations stipulated by Islam, including defense, and vice versa they are entitled to become members of parliament, vote in electing the head of state, and to be appointed to important positions that function to determine the country's political policy.

And for non-Muslim citizens (dhimmy), they get protection of life and bodies, property and culture, beliefs and honor. What is not guaranteed to them is the full right to make political statements. They are not justified in holding key positions in government and positions that formulate state policy and politics. They were also freed from the obligation to defend the country. The highest number of non-Muslims can only sit in the second level DPRD, which does not formulate or decide on political policy. ${ }^{19}$

\section{2) Brief Biography Sayyid Qutb and His Thoughts.}

Sayyid Qutb was born in 1906 in the village of Qaha in the province of Asyut, the son of al-haj Qutb bin Ibrahim, a respected farmer who was relatively located and became a member of the nationalist party. His education began in the village environment and memorized the Qur'an while he was still a child. Realizing his son's talent, his parents moved his family to halwan, a suburb of Cairo. He had the opportunity to enter Tajhiziyah Dar al-

${ }^{18}$ Al-Maududi, The Islamic Law and Constitution, p. 179.

${ }^{19}$ Al-Maududi, Al-Khilafah wa al-Mulk, (Bandung: Mizan, 1996), p. 49. 
Ulum (old name from Cairo University). Then in 1929, he studied at Dar al-Ulum. He obtained his bachelor's degree in education in $1933 .{ }^{20}$

While working as school superintendent at the education department, Quthb was assigned to study in the United States to deepen his knowledge in the field of education. The results of his studies and experiences broaden his insight into thinking about the social problems that are caused by materialism that arid from the understanding of the divine. For this reason, when he returned to Egypt, he became even more convinced that it was Islam that could save people from materialism. Almost unsurprisingly, his concern and talent for polemic brought him closer to the Muslim Brotherhood and joined the group and even became an influential figure, besides Hasan al-Hudaibi and Abdul Qodir Audah. ${ }^{21}$

His radical thought against the government system had caused him to go in and out of prison. Around May 1955, Sayyid Qutb was one of the Muslim brothers who was detained after the organization was banned by president Nasser on charges of plotting to bring down the government. On July 13, 1955, people's court punished 15 years of hard work. He was detained in several prisons in Egypt until mid-1964. He was released that year at the request of Abdul Salim Arif, the president of Iraq, who made a goodwill visit to Egypt. But after only a year he enjoyed freedom, he was again arrested on the charge of conspiring again with the Muslim Brotherhood to kill Nasser. In Egypt based on law number 911 of 1966, the president has the power to detain without proceeding, whoever is considered guilty, and takes over his authority, and take similar steps. Sayyid Qutb with his two friends in the end served the death pinalty on August 29, $1966 .^{22}$

Quthb has so many works. Besides the interpretation of the Qur'an, he produced twenty-four books. He also wrote articles for many magazines, especially al-Risalah, which discussed issues debated by Egyptian intellectuals at the time. His famous work in the fields of politics and statehood is al-'adalah al-Ijtima'iyyah Fii al-Islam, Hadha al-Din, alMustaqbal li hadha al-Din, Maalim fi al-Tariq and al-Madinah al-Manshurah. ${ }^{23}$ From these works political thought can be recognized. For comparative purposes with al-Maududi's thought, several pointers of his thoughts will be described as follows:

\section{a) State establishment}

The need for the establishment of a state (government), expressed clearly, radically and broadly by Quthb. He argued that the establishment of government (state) is a fundamental religious obligation (shar'i). In fact, iqamat al-Din could not be realized without it. In addition, he also believed that it is impossible for human society to be able to achieve optimal social justice if there is no bond to meet their needs. This engagement certainly requires a leadership system (government and state).

More broadly, he wanted the realization of a supra national government. In his view, the entire Islamic world is a political entity under one government without recognizing

\footnotetext{
${ }^{20}$ Ali Rahnema, Para Perintis Zaman Baru Islam, p. 113.

${ }^{21}$ Ali Rahnema, Para Perintis Zaman Baru Islam, p. 115.

${ }^{22}$ Munawir Sadjali, Islam dan Tatanegara, p. 125.

${ }^{23}$ Ali Rahnema, Para Perintis Zaman Baru Islam, p. 116.
} 
national boundaries where regional interests take priority over the interests of the central government. The territory of the country encompasses the entire Muslim world with the decentralization of power in the central government, which is managed on the principle of full equality between all Muslims found in all corners of the Islamic world, without racial and regional fanaticism, even in many respects as well as not recognizing religious fanaticism. Areas outside the administrative center are not treated as colonial territories, nor are they part of the entire Islamic world, and all citizens have the same rights as citizens at the center of government. ${ }^{24}$

\section{b) Mechanisms in Appointing Government Officials}

Qutb did not explain the mechanism for appointing Government Officials, but he discussed it briefly in his book al-'is al-Ijtima'iyyah fii al-Islam. Even then, it is not about the detailed requirements or the mechanism of appointment, and the length of the term of office, but about the leeway that Islam gives Muslims to choose the best way for them by considering the conditions, situations and needs. However, he gave more special attention to the figure and authority of a head of state.

According to him, the head of state must be the result of people's choice and he did not approve of a monarchic or royal form where the head of his country is determined on the basis of heredity. Besides that, he also emphasized that the head of state should be absolutely fair. Head's decisions and policies are not affected by feelings of pleasure or hate, like or dislike, family relations, tribes and other special relationships. In an Islamic state, every individual should enjoy the same justice, without discrimination based on heredity or wealth. ${ }^{25}$

Neither does the feed back given by the people to the authorities. According to Qutb, the obligation to obey the authority holders is an extension of the obligation to obey Allah and His Messenger, because obedience to the holders of power is not because of their position, but because they uphold the shari'ah of Allah and His Messenger. That means that if the holders of authority deviate from the lines set by the shari'ah, then obedient obligations to the ruler will be obliterated, and all orders are not required to be carried out.

In this connection, Qutb argued that an Islamic ruler did not have the religious authority he received from heaven. He became the ruler solely because he was chosen by the Muslims based on their absolute freedom of rights. So if the Muslims are no longer willing to be ruled by him, power is no longer in his hands.

Qutb further stated that an Islamic government must not be formed on a particular system or pattern. Islamic government can adopt any system as long as implementing Islamic sharia. A government that implements Islamic sharia can be called an Islamic government regardless of the form and style of that government. On the contrary, for Qutb, a government that does not recognize Islamic sharia, even if it is carried out by an

\footnotetext{
${ }^{24}$ Sayyid Quthb, al-'Adalah al-Ijtima'iyyah fi al-Islam, p. 95.

${ }^{25}$ Sayyid Quthb. Ma'alim fi al-Tharieq. Kairo : Maktabah Nahdah, 1964, p. 7.
} 
organization that calls itself Islam or uses the label Islam, still cannot be called an Islamic government. ${ }^{26}$

\section{c) Deliberation}

Qutb also considered the role of deliberation important in an Islamic state. According to him, as Allah commanded in Surah al-Imran verse 159, a person to the country must not leave the deliberations. The Prophet himself consulted with his companions on matters for which revelation was not given a clue, and took the opinion of those who were more aware of the intricacies of worldly issues being questioned. Meanwhile, Islam provides broad scope in determining the law for matters relating to the interests of society. Therefore, Islamic authorities have the right to make legal reforms in accordance with the problems they face.

As for the implementation technique, Qutb did not provide a specific explanation, nor did he present the concept of what institutions could realize this consultative function. However, for Qutb, the form of implementation is up to the interests and needs. ${ }^{27}$

\section{d) Nationality}

Like Maududi, Qutb also paid attention to the existence of non-Muslim citizens in the Islamic government. In his view, the Islamic state strongly guarantees the rights of the dhimmis and the polytheists who are bound by a peace agreement with the Muslims. Security must be strictly enforced on the principle of humanity, without distinction between followers of one religion and those of other religions. Islam gives full freedom to the adherents of other religions, and guarantees absolute and perfect equality to the people, and aims at realizing humanitarian unity in the field of worship and social systems.

However, the equality between Muslims and non-Muslims is not really given. This can be seen in positions in government and the right to elect the head of state. He did not hide his position, that these two things are only the absolute exclusive rights of the Muslims. This is because the head of state or priest functions as a substitute for prophethood. So nat urally when the office can only be occupied by people who believe in the prophethood of Muhammad, and also the right to choose it is only limited to the people of Muhammad. ${ }^{28}$

\section{3) Political Thought of Al-Maududi And Sayyid Quthb; A Comparative Study}

Based on the explanation of the above thought, it can be concluded that the views of al-Maududi and Sayid Quthb basically have the same idea. Both products of thought were present in order to react to the socio-political reality of the time and to crave the return of political glory and the dominance of Islam in the past. The ideas promoted by these two figures want an Islamic state, rather than offering a concrete form of government.

${ }^{26}$ Sayyid Quthb. Fi Dilal al-Qur'an. Beiru : Dar al-Ihya' al-Turath al-'Arabi, 1967, p. 47.

${ }^{27}$ Sayyid Quthb, al-'Adalah al-Ijtima 'iyyah fi al-Islam, p. 97.

${ }^{28}$ Sayyid Quthb. Ma'alim fi al-Tharieq, p. 9. 
Although both of them have a similar obsession about the Islamic state, their steps in reaching their obsession certainly have many differences. Regarding the strategy adopted as an effort to empower Muslims in the face of the west, between Maududi and Qutb is full of differences. Maududi was more inclined to the form of cultural movements, while Qutb was more inclined to choose a movement that was revolutionary.

Cultural movement used by Maududi appeared in his efforts to develop the intellectual potential of the people. Thus, it is the educational institution which is the basis for empowering the people's power in facing the west. Maududi believed that the success of an Islamic state depends on its legitimacy in the eyes of society. Because of this, Maududi, unlike most thinkers of the Islamic revivalists who followed him, supported the Islamization of society before creating the state and saw the Islamic revolution as a gradual effort. ${ }^{29}$

The term "revolution for the radical change which he uses," does not refer to his choice of the process or method used by modern revolutionary movements to achieve his goals. In his critical study of the French revolution, Russia and Mustafa Kemal's revolution in Turkey for example, he showed that the revolutionary approach from the west tended towards extremities. If the state was Islamized before the people, the state would be forced to use autocracy to impose its will on people who were not ready and objected. For this reason, according to him, only through the cultural path, the socio-economic, political framework, patterns of human life in material and social terms can change, then a radical change for good can be achieved.

While Qutb, who is more inclined to take the revolutionary path, believes that the existing caliphate system must be maintained in order to symbolize the unity and command of the Muslims in facing the West. For Qutb, jihad is a practical matter that should not be abandoned. Furthermore, he attacked with all-out modernists who refined the notion of jihad, which he claimed was only defensive. Qutb even named them spiritual and intellectual cowards, who tried to serve Islam by separating Islam from its methods, which aimed to destroy all unjust political systems. ${ }^{30}$

The need for worshipers (jama'ah) as the dynamic core of the Islamization process, according to Qutb, is based on the prioritization of the treatise, which is the method used by the prophet in regulating the initial Islamic community. Qutb argued that for the past 13 years the Koran was revealed in Mecca as a confrontation, by challenging the licensing of the people of Mecca, encouraging the interaction of members of the community. At the same time, the Qur'an focuses on the ideological maintenance of the congregation, by giving them certainty of Divine support and the strength to remain persistent in their struggle against the oppression of the people of Jahili, their place of residence.

On the other hand, between Mawdudi and Qutb turned out to work at two different levels of reasoning. One in terms of fundamental religious commitments, and the other, in terms of a series of simple practical problems. It can be said elaboratively that, Mawdudi tends to have a rigid and textual interpretation of Islamic doctrine in his socio-political discourse, while Qutb has a broader and general interpretation.

\footnotetext{
${ }^{29}$ Al-Maududi, al-Khilafah wa al-Mulk, p. 49.

${ }^{30}$ Sayyid Quthb, al-'Adalah al-Ijtima'iyyah fi al-Islam, p. 95.
} 
Understanding Islam as a monolithic ideology in Maududi's thought became a source of strength and authoritarianism in his thinking. This is seen in his interpretation regarding the shape and character of an Islamic state. He noted the areas of concern for women's rights, minority rights, and economic behavior. He paid little attention to socio-economic problems such as population growth, economic injustice, and social injustice. He believed that all these problems are not really matters that need attention, because this is a symptom of the absence of an Islamic order, and also reflects the failure of western ideology. This problem will disappear once the state and society have been Islamized.

Therefore, he advised Muslims not to think about these matters, but pay more attention to the establishment and management of an Islamic state. So that the teachings of the economy are then more politically conservative. Neither is the role of women and minorities in Islamic countries. He argued that Islamic law is clear on these matters, so that the Islamic state only needs to think of ways to accommodate it. Islamic State only applies what is outlined by shari'a. The question of minorities, said Maududi, has been covered in discussions about dzimmi (Muslim minorities) in Islamic law and the issue of women covered in various rules that determine the modesty of dress and women's rights in Islamic society. ${ }^{31}$

In contrast to Qutb, Maududi's interpretation on dzilal al-Qur'an is one of evidences of the looseness of his thinking. This interpretation is an interpretation that does not use the traditional interpretation method alone, but a method that always refers to other established authorities. And instead, Qutb expresses a personal reaction and spontaneity of his thought to the verses of the Qur'an. This was reinforced by referring to other Islamic writers, such as Maududi himself, Abbas Aqqad and others who became his classical authority. Qutb argued that the ideal Islamic order should be firmly established through rational means. He advocated the method of interpreting the commands of Allah such as Sadd al-Dzara'i and the problem of the problematic as well as his specific information about this method. ${ }^{32}$

Besides that, Maududi was an ideologist. His utopian thinking was admitted by himself in his idea of an Islamic state which turned out to be more fanciful and ideal. In some places, he talked about the characteristics of an Islamic state which could be implemented only in the context of an realized Islamic society which cannot be found now. So, he was not talking about urgent and immediate problems from real Pakistan and far from ideal, but rather an ideal concept of a perfect society, which is expected to be realized in a short time.

As long as politics, according to the old adage, is an art of possibility, Maududi never talked about political reality, except only at the level of general ideas. He was more preoccupied with administrative functions and the constitution of an Islamic state. The aim is to prove that the Islamic state, besides being ideal, must be an effective entity that outperforms the western and socialist models. He believed that the state was needed, because it was effective and superior, not because of mere religious support. The ethical

\footnotetext{
${ }^{31}$ Al-Maududi, al-Khilafah wa al-Mulk, p. 53.

${ }^{32}$ Sayyid Quthb, al-'Adalah al-Ijtima'iyyah fi al-Islam, p. 98.
} 
needs and functions of an Islamic state and its utopian image are based on the rhythm between their ideals and the aspirations of the people.

Meanwhile, Qutb was a realist and pragmatic. According to him, Faith will not only change the way individuals view the world, but will also provide behavioral programs that are political action programs. Qutb asserted that the Qur'an gave humanity the means to rediscover itself in the pattern desired by the prophet and, through the prophet, by Allah. ${ }^{33}$

Therefore, Qutb's interpretation emphasizes much the need for humans to apply this knowledge of faith, through direct action into life, not only individual life, but also social life and political order. The point is no less than re-creating the Qur'anic generation. Therefore, Qutb urged Muslims to emulate the founders of the Islamic community, who embraced Islam as an experience of personal transformation in Mecca, and then proceeded to establish it realistically in the Islamic realm, and thus create an ideal community that was not only on abstract ideas, but also concrete ideas. ${ }^{34}$

\section{4) Fundamentalism In Modern Islamic Political Discourse}

The root of the problem of the rise of Islamic fundamentalism in modern politics began with the interpretation of the practice of the Prophet's preaching in Medina. Question, is the Prophet only acting as an Apostle or concurrently as a king? Has he ever founded a country? And is establishing a state an inhern task from the apostolic treatise? The answer is very diverse. For those who say yes, they will be obsessed with implementing an Islamic state in their territory to follow the shari'a and the Prophet's guidance. This thinking underlies the perspectives of al-Maududi and Sayyid Quthb about the integrated relationship between religion and state.

If it is mapped, it will appear the relationship between religion and the state in the realm of contemporary Islamic thought is divided into three groups, namely: first, the thought of al-Maududi, Sayyid Quthb and Hasan al-Banna about the relationship of religion and state that are integrated. Religion and state cannot be separated. Religion as a rule already contains all the problems of human life, including regulating the country. What the Prophet did was final. Prophet Muhammad is an apostle and leader of the country at the same time. Second, the thoughts of al-Mawardi and al-Ghazali about the relationship of religion and the state which have a mutualistic symbiotic pattern, meaning that religion and the state need each other. Religion needs an ethical foundation to regulate society and religion needs the state as a place to develop it. Third, the thoughts of Ali Abdul Razieq and Thaha Hussein about the relationship between religion and a secularist state. Religion and state are two different entities. There is a religious territory and there is a country territory.

The Koran as the main source of Islamic teachings, besides it is a unique phenomenon in the history of human civilization, it is also the bearer of the treatise which gives privilege to human reasoning and intellect. With the system of reasoning, human thought develops. Even with the intelligence of this thought, humans incarnate as interpretive creatures of

\footnotetext{
${ }^{33}$ Al-Maududi, al-Khilafah wa al-Mulk, p. 55.

${ }^{34}$ Sayyid Quthb, al-'Adalah al-Ijtima'iyyah fi al-Islam, p. 99.
} 
reality, both textually and contextually. In relation to the interpretation of the Koran, humans have the ability to open horizons or perspectives, especially in providing interpretation of verses that contain dhanni al-dilalah (unclear statement). From this, it cannot be doubted that the Koran contains verses that form the basis of ethics and morals in building socio-political systems. It also includes that the vision of the universality of the Koran finds its relevance to the ideals of universal humanism.

In addition to the above understanding, there is also an interpretation that says that the Koran contains the rules of various dimensions of human life (holistic). This includes regulating the system of government and the formation of an Islamic state. Through this kind of interpretation system then emerges in the realm of interpretation, an understanding which states that the Koran is actually the foundation of political theology. Those who argue with this view, usually base the logic of its interpretation on verses of the Koran textually. As in Surah al-Ma'idah (5), verse: 3; "On this day I have perfected your religion for you, and I have provided you with my favors, and I am pleased that Islam has become a religion for you." This verse also confirms Surah al-An'am (6), verse: 38; "We have not forgotten anything in this book."

The last verse above briefly gives an understanding and implies that various dimensions of human life are contained in the Koran. The phrase of the Koran "We have not forgotten anything in this book. "If this verse is traced in its historical realm, the verse does not stand alone. The context of this verse is talking about the perfection of Allah's knowledge and His power. Thus, the life of the world with all its contents - including animals and humans - with all its problems is actually inseparable from God's observations. In this case Rasyid Rida understands the verse, that what is meant by "al-kitab" in surah alAn'am (6): verse 38, is al-lauh al-mahfud, a kind of big book that holds a blueprint for God's creatures, not the physical Koran that exists on earth.

Meanwhile, in Surah al-Nahl (16): verse 89 which states "We sent down this book to you to explain everything", has a different understanding as well. For example, by quoting the interpretation of Ibn Kasir, one of the famous classical commentators, he said that what was meant by "explaining" in the verse was to give understanding and explain all that was allowed (halal), and all that was forbidden (haram), not other understanding.

With this interpretation of Ibn Kasir, it can be concluded that these verses explicitly do not provide an understanding that the Koran contains everything as is believed among Muslims. On the other hand, if we look at the verses which number about 6236, which talks about the problem of state law (al-ahkam al-dauliyyah) there are only 25 verses. Even those 25 verses, talking about matters of state law, the Koran only touches on principles and outlines. On the contrary, most of the verses in the Koran express the history and civilization of the Prophet's people and previous Apostles. With reference to this understanding, it appears that the Koran is not a book of legislation. But it is as a guide (hudan), a differentiator between right and wrong (furqan), explanatory (tibyan), and as a warning (Dhikran).

Some Muslims have an understanding that Islam in reality is not just a religious doctrine that guides people from the spiritual aspect, but also tries to build a system of state administration. According to this paradigm, Islam as a religion can also be interpreted as a 
political institution and state as well (al-Islam Diin wa Daulah). In a holistic perspective, Islam does not only regulate human relations with God, but also contains teachings about relationships between human beings, both in the social and political aspects of the state. By taking the doctrine of "Inna al-Islam Din wa Daulah" (Indeed Islam is a religion and state), Islam was finally understood as political theology. Islam eventually becomes a necessity, especially in the effort to position Islam as the basis of the state. In that format too, Islam is a typical sociopolitical, where the functions of religion and politics cannot be separated but must be formed formally-legalistically in a forum called "Islamic State". ${ }^{35}$

Such Islamic political ideas became the first typology of the Islamic movement which in history can be referred to for example in two large organizations, namely al-Ikwan alMuslimun in Egypt and Jama'at al-Islamiyyah in Pakistan. Both organizations are moving towards strengthening the Muslim base as their political capital and placing Islam as the ideology of their movement. Both of them are moving based on strong political theology and are rooted in their ideas and attitudes as advocates of the Islamic fundamentalist movement. In their movement strategy, these two organizations have an orientation, in addition to implementing Islam in the life of the nation and state, both of these organizations wish to place Islam as a basic ideology in their respective countries.

In its development, these two organizations had a major influence on the rise of the Islamic movement in various countries, both minority and Muslim majority. The movement that emerged by al-Ikhwan al-Muslimun and Jama'at al-Islamiyah has been an inspiration for similar movements in Islamic organizations in many countries. Even though their movements are faced with various obstacles, for example with secular groups, in many strategies they take the path of (1) opposition to the authorities, (2) becoming the ruler and even (3) there are coalitions with other organizations that are ideological in order to gain power. However, the obstacles and challenges of the Islamic fundamentalist movement in many Muslim countries are confronted with nationalist groups who adhere to the principle of nation-state and ethnic, linguistic, cultural and geographical similarities. Much literature said that the equivalent of this fundamentalist Islamic movement is with a number of terms such as militant Islam, revivalist Islam, some even mention neo-fundamentalist. The sentences that are often campaigned by these groups are none other than explicitly rejecting the secular state or nationalist state and trying as much as possible to establish an Islamic state.

The second group of Islamic movements that developed today are Muslim communities that tend to emphasize the separation between religion and state. This second group has political ideals to make secular country. They hold to the theoretical paradigm which states that religion does not emphasize the obligation to establish the state at all. Religion, according to them, only provides ethical and moral values in building the fabric of society and the state. According to this group, there is no verse of the Koran that explicitly requires Muslims to form a government and a state. This group often uses a contextual interpretation system in approaching its religion. In addition, in the framework of their theological beliefs, they stated that the establishment of Islamic government and state was

\footnotetext{
${ }^{35}$ Bakhtiar Effendy, Islam dan Negara, p. 178
} 
not included in the task as revealed by God to the Prophet Muhammad. He was only an Apostle who merely brought religious vocation which did not include the order to establish a country. The Prophet was only given the mandate to develop the vision and mission of the universality of Islam in managing plural humanity.

This second group also makes a strong argument. According to this group, the Islamic State is not only conceptually unproven and difficult to find in various Islamic literature, but also finds its ambiguity when implemented in a practical area. The main factor that makes this ambiguity lies in practical issues, for example which party is considered to have the authority to determine the Islamic quality of a country and what criteria are used. This second group in various Islamic political literature is often referred to as adherents of the secular school and categorically this school also gives birth to at least two polarizations. First, groups that have a secular-moderate paradigm. This group firmly states that the problem of religion is an individual matter and the state has no right to intervene. On the other hand, this secular-moderate group said that the state still respects the religion of its inhabitants. This has become one of the forms of tolerance of the state towards religion, that is, it can take the form of legalizing religious institutions or religious symbols in the life of the nation and state.

Unlike the first, the second group tends to embrace extreme secularism. This group places religion not only as a private matter, but religion in the public sphere is something that is prohibited and even its adherents were confined and oppressed. In this extreme secular state, the state does not give the slightest tolerance to followers of religion, even the existence of religion itself is often a victim of state politics. This extreme-secularism paradigm might find its original form, where the principle of separation between religion and state is strongly held.

However, the existence of a secular state in many countries gives different responses, especially in treating religion. There are at least four criteria for a country to be categorized as a secular state, namely: First, there is a separation between government and religious ideology. Second, there is the development (expansion) of the government to further carry out its role and function in overseeing religious matters. Third, a reevaluation of political culture by replacing religious values with secular political culture. Fourth, its relationship with power, the state is tasked with erasing religious values and religious practices.

From the four categories above, religious and state relations that embrace secularism in history have been shown to the government of Mustafa Kamal Attaturk in Turkey. Under his rule, Turkey was governed by basing it on the ideology of a secular state. But in the development of his government, Turkey continued to be under the shadow of extremely acute religious and state relations and gave birth to organizations with a religious background as an ideology that often made movements against the ruling government. Secularism which actually requires a strict separation between religion and state, in reality it actually buries the militant movement based on religion.

The third group is those who take the paradigm of substantive thinking. According to adherents of this school, the relationship between religion and the state must be in a symbiotic relationship, which is a mutual relationship that needs each other between the two. According to this group, the state needs ethical and moral guidelines as taught by 
religion. Likewise religion also requires a state escort for its preservation and existence. Through this relationship, the two are in a mutualistic symbiotic dimension.

The style of political theology that holds this group is that the relation of religion and the state is based on ethical principles. As substantial followers, they assert that the standard guidance on the political system and governance in Islam is not found and proven at all. Theological beliefs like this for them to be legitimate, because argumentatively there is not a single concept in the Koran that clearly contains provisions regarding the source of state power, how that power is obtained, to whom the authority is responsible and so on. Based on such logics, this school firmly states that Islam does not at all oblige its people to make Islam the state ideology. According to this school, the holistic nature of Islam does not automatically mix the sacred (religious values that are universal) and the profane (political organization, political ideology, state formation and so on) in the dimensions of national and state life. This school is thus more oriented towards the values and substance of religious teachings. In the order of public life, this school always reflects and seeks to internalize the principles of Islamic teachings that are universal. ${ }^{36}$

This Islamic political paradigm which according to Bakhtiar Effendi is seen as a "new" religio-political perspective on the relationship between Islam and the state which tends to be "theological". According to him, there are 4 principles that strengthen this substantive shcool; first, that the Koran and al-Sunnah do not explicitly require Muslims to establish an Islamic State. Second, Islam only provides a set of basic socio-political principles. Third, Islam is understood as an eternal and universal religion. And fourth, that only Allah Who has and knows the absolute truth. ${ }^{37}$

Apart from the three categories above, if it is explored in depth about the role of Islam in the life of the nation and state, it will be found many things that are recommended, especially with regard to universal principles in realizing a just and prosperous society. These principles cannot be separated from universal values as contained in Islam. These principles include; the principle of al-shura (consultation) (QS. Ali Imram: 159), the

${ }^{36}$ Abdurrahman Wahid divides two major groups of Muslim views on nationalism, (1) groups who want to apply more manifestations of state and community life with a clear Islamic color and (2) groups who want to apply Islam socially and culturally in the life of the nation. The first group is more concerned with a formalistic legal approach to Islam in the sense of the application of Islamic values in the country's laws and regulations. The argument of this group is that in reality that Muslims are the majority, and religious teachings can be legalized through institutions of representative of the people representing the majority of the nation. Followers of this group formally demand bureaucratic positions with majority representation. While groups that use the socio-cultural approach do not attach importance to the formal form of religion, and hence they do not worry about the problem of the state leadership and the government system. The nationalist insight that emerges is an integral insight which is the result of the meeting point of the equality of universal values that are embraced and recognized by all elements of the nation. Islam can be used as one of the pillars of national insight in national life. (Abdurrahman Wahid, State Institution, Religion and Culture, (Jakarta: Desantara, 2001), p. 94-95).

${ }^{37}$ Bakhtiar Effendy, Islam dan Negara, p. 134 
principle of al-musawa (equality) and al-Ikha' (brotherhood) (QS. al-Hujurat: 13), the principle of al-'adalah (justice) (QS al-Ma'idah: 8), Principle of al-hurriyyah (freedom) (Surah al-Baqarah: 256), Principle of al-amanah (trust) (Surah al-Nisa ': 58), Principle of al-salam (peace) (Surah al-Anfal: 61), Principle of al-tasamuh (tolerant) (Surah al-Baqarah: 256 and Surah al-Kafirun: 6).

In this conception, it seems that it needs to be emphasized and distinguished between Islam in its historical aspects and Islam in its doctrinal aspects. The principles that are of universal value would be very adequate to be the basis in living as a state and society, without having to realize them in a formal state, namely an Islamic state. Universal religious ethics and morals can also be accepted in complex state life and require a comprehensive approach to handling them.

Based on the explanation above, both Islamic groups who see the relationship between Islam and politics textually and tend to fight for Islam as a political ideology in the establishment of an Islamic nation state or Islamic caliphate and Islamic groups that only agree with the idea of a nation state that is considered secular, both have the same desire, namely the desire of Islam to color the lives of the world community in general, and Indonesian society in particular. There is even a more interesting notion of shifting from the statement "Islam al-Diin wa al-Daulah" to "Islam al-Diin wa al-Ummat". The second statement seems to be a middle ground of differences of understanding among Muslims about religion and the nation state, namely religious nationalism or Islamic nationalism. ${ }^{38}$

\section{CONCLUSION}

From the explanation above it can be concluded that the two figures have a similar obsession about the Islamic state. But they are different in the following three ways: First, the strategy adopted. Maududi was more inclined to the form of cultural movements, while Qutb was to choose a revolutionary movement. The cultural movement by Maududi is evident in his efforts to develop the intellectual potential of the people. In this case, educational institutions are the basis of forging the people's power in facing the west. Qutb argued that the existing caliphate system must be maintained in order to symbolize unity as well as the command of Muslims in confronting the West. For Qutb, jihad is a practical matter that should not be abandoned. The second difference is between Mawdudi and Qutb apparently working at two different levels of reasoning. One in terms of fundamental religious commitments, and another, in terms of a series of simple practical problems. Maududi tends to have a rigid and textual interpretation of Islamic doctrine in his socio-political discourse, while Qutb has a broader and more general interpretation. The Third difference is that Maududi is an ideologist, while Qutb is a political practitioner. Maududi never talked about political reality, except only at the level of general ideas. He is more preoccupied with administrative functions and the constitution of an Islamic state. His thinking aims to prove that an Islamic state, besides being ideal, must be an effective entity that outperforms the western and socialist models. While Qutb is as a realist-

${ }^{38}$ The idea of al-Islam Dinun wa Ummatun as a criticism of the idea of al-Islam Dinun wa Daulatun is the idea of Shaykh Jammal Banna, namely Hasan al-Banna's younger brother who is a bearer of the ideas of al-Islam Dinun wa Daulatun. Jamal Banna's idea was written in a book called "al-Islamu Dinun wa Ummatun wa laisa Dinun wa Daulatun" 
pragmatic. According to him, Faith will not only change the way individuals view the world, but will also provide behavioral programs that are political action programs. Qutb asserted that the Qur'an provides the means for humans to rediscover themselves in the pattern desired by the prophet and, through the prophet, by Allah.

\section{REFERENCES}

Abdurrahman Wahid, Pergulatan Negara, Agama dan Kebudayaan, (Jakarta: Desantara, 2001). A Syafii Ma'arif, Peta Bumi Intelektualisme Islam di Indonesia, (Bandung: Mizan, 1993).

Abdurrahwan Wahid, Mencari Format Hubungan Agama Dengan Negara, dalam Kacung Marijan (Ed), Mengurai Hubungan Agama dan Negara, (Jakarta: Grasindo, 1999).

Ali Rahmena, Para Perintis Zaman Baru Islam, (Bandung: Mizan, 1996), p. 111-112.

Al-Maududi, The Islamic Law and Constitution, (Labore: Islamic Publication, 1975), Edition 5, . Al-Khilafah wa al-Mulk. Terj. Bandung : Mizan, Cet I, 1996.

Anton Bakker dan Achmad Charris Zubair, Metodologi Penelitian Filsafat, (Yogyakarta: kanisius, 1990).

Azyumardi Azra, "Fenomena Fundamentalisme dalam Islam; Survei Historis dan Doktrinal" in Ulum al-Qur'an, nomor 3, Vol IV, 1993.

- Pergolakan Politik Islam dari Fundamentalisme, Modernisme hingga PostModernisme. Jakarta: Paramadina, 1996.

Ali, Fachry. Golongan Agama dan Etika Kekuasaan: Demokratisasi dalam Islam Indonesia. Surabaya: Risalah Gusti, 1996.

Arkoun, Muhammad. Rethinling Islam. San Fransisco: Westview Press, 1994.

Bakhtiar Effendy, Islam dan Negara.

Bahadur, Khalim. The Jama'at al-Islami of Pakistan. New Delhi, 1979.

Effendy, Bakhtiar. Islam Dan Negara: Transformasi Pemikiran Dan Praktik Politik Islam di Indonesia. Jakarta: Paramadina, 1998.

Elposito, John L. Islam and politics. New York: Syracuse University Press, 1987.

The Oxpord Encyclopedia of the Modern Islamic World. New York : Oxford University Press, 1995.

John L Elposito, Islam and politics, (New York: Syracuse University Press, 1987).

John L. Esposito, Dinamika Kebangkitan Islam; Watak, Proses dan Tantangan, (Jakarta: Rajawali Press, 1987).

Klaus Krippendorff, Content Analysis; Introduction to Its Theory and Methodology. Translated by Farid Wajidi, (Jakarta: Rajawali Press,1981)

Kuntowijoyo. Identitas politik Umat Islam. Bandung:Mizan, 1997.

Mukti Ali, Alam pikiran Islam Modern di India, (Bandung: Mizan, 1993).

Munawir Sadjali, Islam dan Tatanegara; Ajaran, Sejarah dan pemikiran, (Jakarta: UI Press, 1990). 
Munawwir Sadjali, Islanm dan Tatanegara; Ajaran, Sejarah dan Pemikiran, (Jakarta : UI Press, 1990).

Mahendra, Yusril Ihza. Maududi dan Jama'at al-Islami dalam Ulum al-Qur'an, Nomor 3. Vol. IV. 1991

P.J. Vatikiotis, Islam And The State, (London And New York: Routledge, 1987).

Sayyid Vali Reza Nasr in Ali Rahnema, Para Perintis Zaman Baru Islam, (Bandung, Mizan: 1996)

Sayyid Quthb. Ma'alim fi al-Tharieq. Kairo : Maktabah Nahdah, 1964.

Sayyid Quthb. Fi Dilal al-Qur'an. Beiru : Dar al-Ihya' al-Turath al-'Arabi, 1967.

Sayyid Quthb, al-'Adalah al-Ijtima'iyyah fi al-Islam, Kairo: Dar al-Shuruq, 1979. 